\title{
The impact of informal settlement on water quality of Diep River in Dunoon
}

\author{
Babalwa Gqomfa $^{1}\left[\right.$ ] Thabang Maphanga ${ }^{1} \cdot$ Karabo Shale $^{1}$
}

Received: 28 March 2021 / Accepted: 9 January 2022 / Published online: 21 January 2022

(c) The Author(s) 2022

\begin{abstract}
Water quality is declining due to the rise of urbanization, overpopulation, industrial production, climate change, non-compliance of wastewater treatment plants, and agricultural waste. The mushrooming of informal settlements along the bank of the Diep River due to population growth in Dunoon compromises the quality of water. Inadequate sanitation and waste disposal practices in the Dunoon informal settlement are a major problem, leading to the contamination of water resources. This research aimed to investigate the impact of Dunoon informal settlement on the Diep River water quality. Water samples were collected for 4 months from four sites of the river to cover the spatial distribution. The laboratory determined the concentrations of nitrates, phosphates, dissolved oxygen, chemical oxygen demand, total suspended solids, and E. coli, while the field study used a multiparameter reader to determine turbidity, temperature, electrical conductivity, $\mathrm{pH}$, salinity, and dissolved oxygen. The results were compared with the South African water quality guidelines for irrigation, recreation, and aquatic ecosystems, and South African National Standards. The study revealed that the average concentrations of $E$. coli, dissolved oxygen, electrical conductivity, salinity, turbidity, chemical oxygen demand, and ammonia exceeded the recommended limits in both the wet and dry seasons. Based on the findings, the water quality in Diep River is poor and the Dunoon informal settlement has contributed to this to some extent. The pollution of the river may be linked to health problems and environmental degradation. Considering this, the waste discharged into the neighbouring aquatic environments needs to be monitored and managed frequently.
\end{abstract}

Keywords Informal settlements · Water quality $\cdot$ Water pollution $\cdot$ Environmental impacts $\cdot$ Health impacts $\cdot$ Water legislation

\section{Introduction}

South Africa has limited water resources as it is a semiarid country, and poor management of water quality could result in water being unavailable to several users. Water is an essential component in the existence of every living organism; hence the protection of water resources is of utmost importance. Major contributors to water quality deterioration in South Africa's water resources are agricultural runoff, management of wastewater treatment infrastructure, industrial activities combined with a general decline in the operation, and household waste both solid and liquid

Babalwa Gqomfa

bgqomfa@gmail.com

1 Department of Environmental and Occupational Studies, Faculty of Applied Sciences, Cape Peninsula University of Technology, Cape Town, South Africa which gets disposed of in an improper way (Xue et al. 2015). Water resources of good quality provide a precondition for economic development and ecological integrity (Cao et al. 2019).

These wastes have hazardous chemicals and toxins that poison the water, harming aquatic plants and animals. The alteration of land use due to urbanization and agriculture causes precipitation to run off quickly, resulting in severe erosion, flash flooding, reduced groundwater, recharge, and wildly fluctuating streamflow. One of the major challenges that emanate from informal settlements that exist along riverbanks is that people tend to do laundry in the river, as was the case with one of the Alexandra informal settlements called Stjwetla closest to the Jukskei River (Mawela 2008). Urbanization is a major cause of the rapid spread of informal settlements. Many people moving from rural areas cannot afford houses, and so build shacks in the most vulnerable areas such as wetlands, riverbanks, and so on. Informal 
settlements are sometimes located in the most unfavorable conditions such as those that are close to water bodies (Tsenkova 2010). The Nairobi River in Kenya, for example, is largely used by populations of low income, especially those living in informal settlements, as a source of water for washing, cleaning, and watering crops (Mbui 2019). Furthermore, it is also used to dump domestic and human waste as several homes lack toilet facilities. Industrial waste is also regularly discarded in the river (Mbui 2019).

The contamination of water bodies is associated with substantial negative health issues and mortality. Given this, there is a need for frequent monitoring and managing or controlling waste products discharged into the neighboring aquatic environments. This study seeks to investigate the causes of the decline in the Diep River water quality and whether the Dunoon informal settlement contributes to this decline. It also seeks to determine the environmental and health impacts resulting from pollution.

\section{Methodology}

The study looked at the impact of informal settlements on the surface water, as there are few studies in South Africa that have focused on the impact of informal settlements on water quality. Qualitative and quantitative methodologies were used for this study. The qualitative approach was chosen because it reinforces the understanding and interpretation of meaning as well as the motives and attitudes of humans, while the quantitative approach is chosen because it is more measurable and can be tested, and results are more precise and accurate. Primary data were collected by the researcher from first-hand sources using questionnaires, observations through a checklist, and lab tests. The purpose of the questionnaires was to assess the Dunoon community's level of awareness and to assess their knowledge, attitudes, and practices towards river water pollution, waste management, as well as what they thought needed to be done to prevent the problems arising from pollution. The sample size was 249 people residing in Dunoon informal settlement. Samples of water from the Diep River were collected to test the quality of water. These tests were done over 4 months (two tests in winter, and two in summer) at different strategic points of the river. One point was close to the Dunoon informal settlement (ISD), the second point was close to the farm opposite the Dunoon informal settlement (MAL), the third point was the part of Diep River close to where the wastewater treatment plant discharges its treated water (PWP), and the fourth point was where there are no informal settlements, industries, or farms (MGC). The $\mathrm{pH}$, dissolved oxygen, conductivity, and temperature of the river were measured on-site using a portable HANNA-HI 9829 multiparameter reader. The water was also tested for $E$. coli, total suspended solids, chemical oxygen demand, ammonia, phosphates, and nitrates in an accredited lab. To analyze the data, the SPSS software version 25 was used. Permission to use the Outa sampling results report for the Diep River area was also requested and the raw data were analyzed. The Outa results were for samples that were taken from January to April of 2020. The averages shown in the bar charts were calculated using SPSS, by dividing the sum of a set of quantities by the number of quantities in the set.

\section{Study area}

Dunoon is a township situated in Milnerton, a suburb in Cape Town (Western Cape, South Africa). It is located around relatively affluent areas such as Parklands, Table View, Killarney Gardens, and Richwood. Although water supply is a problem in other informal settlements, the natural resource (Diep River) that runs through Dunoon is highly polluted mainly due to poor sanitation, inadequate waste collection, and other factors. According to a South African Government Gazette promulgated on the 6th of November 2020, the Diep River is one of the sub-catchments under the Berg Catchment area (DWS 2020). It is classified as Class III, which indicates sustainable minimal environmental protection and high utilization. The Diep River water is mainly used for irrigation and recreational purposes, however, the quality of water in the river has been declining (Western Cape Government 2020). The river is surrounded by informal settlements, wastewater treatment plants, factories, industries, and farms. Figure 1 shows the sampling sites of this study within the Diep River.

\section{OUTA sampling sites}

The Outa sampling sites (see below) were different from the sites shown in Fig. 1, and they were:

M14-Located in the Diep River at Blaauwberg Road in the M14 Road.

PDA-Pond is located at the Potsdam Waterworks where the water is discharged into the river after treatment.

PDB-After Potsdam water treatment works.

TMS - Theo Marais Canal close to the Koeberg pump station

MCC-Milnerton lagoon at Woodbridge.

PDD-After Potsdam sewage works close to Theo Marais.

PDC-Potsdam water treatment plant temporary discharge into the river (Greggorr 2020). 


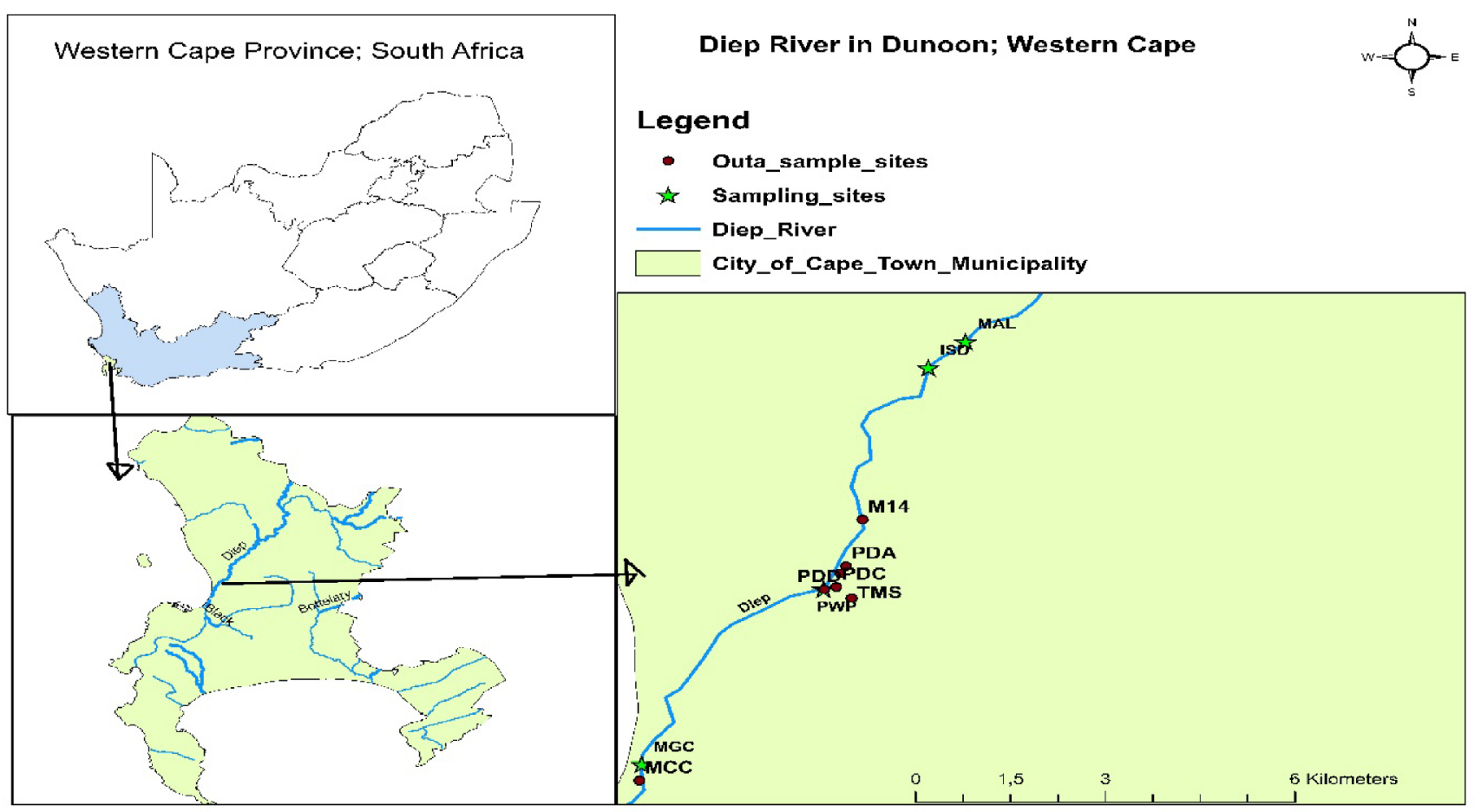

Fig. 1 Study sampling sites

\section{Results and discussion}

\section{Water temperature in all four sampling sites}

Figure 2a shows the results of water temperature at the four collection points. PWP had the highest average water temperature of $19.5^{\circ} \mathrm{C}$, while ISD had the lowest average water temperature of $15.8^{\circ} \mathrm{C}$. The results show that the average water temperatures of the different sites were around the same mean. The average temperature reading for all the sites during the wet season was $12.1{ }^{\circ} \mathrm{C}$. This is because the wet season was in winter, while the dry season was in summer. The temperature results were slightly different from those in a previous study of the Diep River conducted by Awe in which, for the four seasons, the average temperature range was 14.0 and $24.2{ }^{\circ} \mathrm{C}$ (Awe et al. 2020), while the range in this study was between 15.8 and $19.5^{\circ} \mathrm{C}$. The slight temperature difference could be attributed to the fact that the samples were taken on different days and times. Both studies indicated that temperatures were generally lowest in winter and highest in summer.

Various factors affect water temperature, and these include air temperature, groundwater inflows, stormwater runoffs, turbidity, and sunlight exposure. It is essential to consider both maximum and optimum temperatures when it comes to the health of organisms. The tastiness, viscosity, solubility, smell, and chemical reactions are affected by temperature (SDWF 2018). The variation in river water temperature generally depends on the season, physical location, time of sampling, and temperature of effluents entering the stream. Sometimes the temperature variations may be the reason for an increase of alien species and a decrease in the diversity of native species (Wolf et al. 2014). High temperatures may increase the toxicity of the water for domestic use. The observed water temperature was also below the $25^{\circ} \mathrm{C}$ acceptable limits for no risk, recommended by the World Health Organization.

\section{The $\mathrm{pH}$ results in all four sampling sites}

Figure $2 \mathrm{~b}$ shows the analysis of $\mathrm{pH}$ results from the four sampled sites of this study. MGC had the highest $\mathrm{pH}$ average of 8.4, while the lowest was at ISD with a $\mathrm{pH}$ of 7.4. The $\mathrm{pH}$ of all the sites was clustered around the mean of 7.9. The South African water guidelines indicate that water should have a $\mathrm{pH}$ range of 6.5-8.4 for irrigation purposes and 6.5-8.5 for recreational use (DWAF 1996). The average $\mathrm{pH}$ of all the sites fell within these ranges. Only PWP and MGC recorded $\mathrm{pH}$ levels greater than 9. The average $\mathrm{pH}$ during the dry season was 8.2 , compared to 7.2 during the wet season.

The $\mathrm{pH}$ measures the concentration of hydrogen ions and indicates the relative acidity or alkalinity of water. For drinking water, the ideal $\mathrm{pH}$ range is $6.5-8.5$, as defined within the WHO standards). When the values of $\mathrm{pH}$ are high, it signifies that there is a high level of chloride, bicarbonate, 

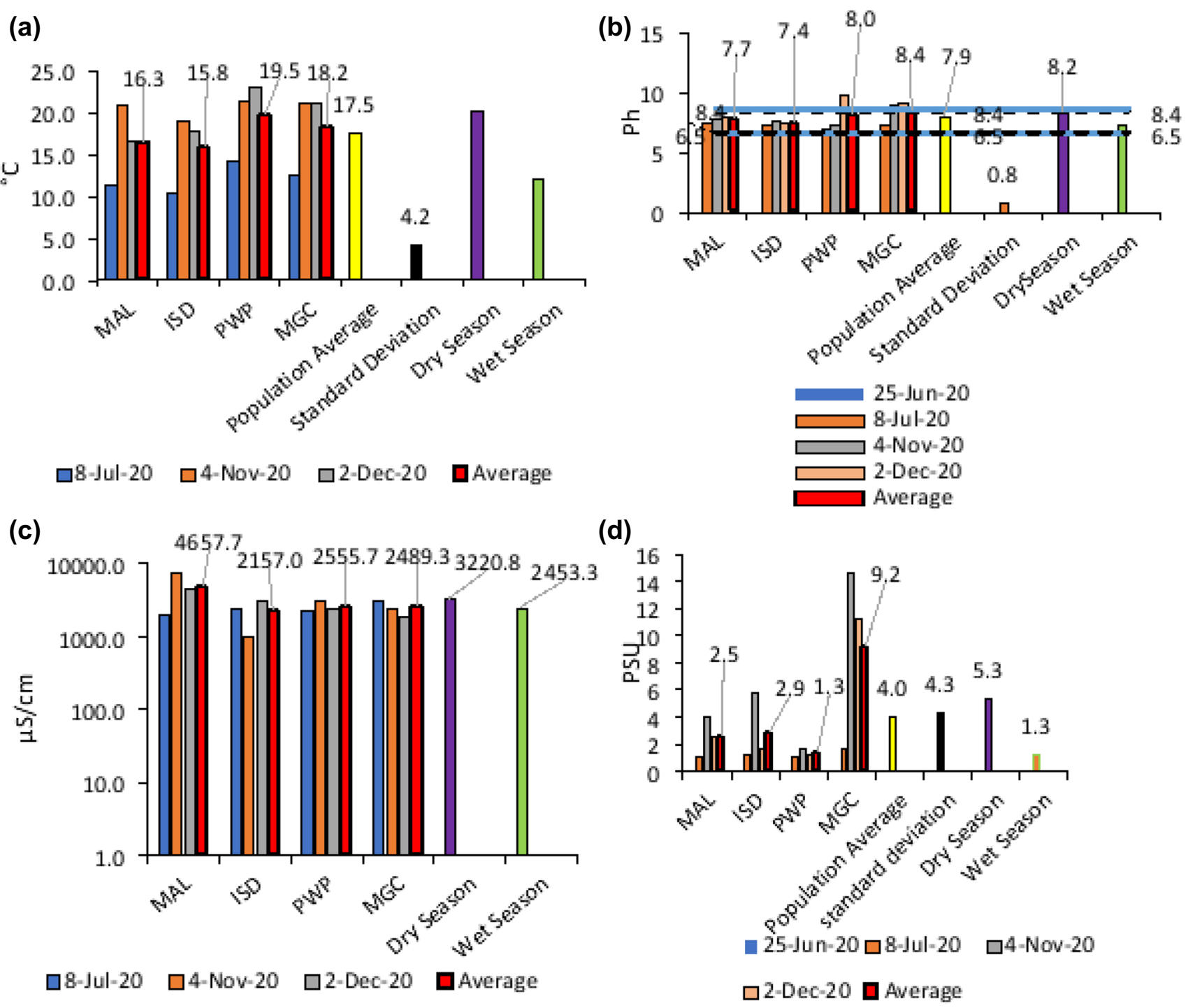

Fig. 2 Temperature, $\mathrm{pH}$, electrical conductivity, salinity results

or carbonate, to name a few. That means the water is alkaline (Uddin et al. 2014). For domestic water use, the permissible $\mathrm{pH}$ range in South Africa is 6-9 and, based on the results, the average of all sites fell within this range (DWAF 1996).

The $\mathrm{pH}$ results in this study were slightly higher than those obtained by Awe in a previous study conducted in Diep River, even though they were both within the recommended limits for domestic, recreational, and agricultural water use. The average water $\mathrm{pH}$ range recorded in Awe's study was 7.16-7.98 (Awe et al. 2020), whereas the $\mathrm{pH}$ range in this study was 7.4-8.4.

\section{Electrical conductivity (EC) in all four sampling sites}

Electrical Conductivity refers to the measure of a solution's capability, such as water in a stream, to pass an electric current. It indicates the concentration of dissolved electrolyte ions in the water. An indication of an increase in conductivity may signify that polluting discharges have entered the water. In the ideal world, freshwater streams should have a conductivity between 150 and $500 \mu \mathrm{S} / \mathrm{cm}$ to support diverse aquatic life (Mathur 2015).

Figure $2 \mathrm{c}$ shows the EC results for the four sampling sites. MAL had the highest EC levels at $4657.7 \mu \mathrm{S} / \mathrm{cm}$, while ISD had the lowest, recording $2157 \mu \mathrm{S} / \mathrm{cm}$. The MAL EC levels were twice as high as that of ISD. MAL was an outlier with high levels of EC, whereas the rest of the sites were clustered around the same mean. The EC levels during the dry season were over $1000 \mu \mathrm{S} / \mathrm{cm}$ higher than those of the wet season. According to South African National Standards, the conductivity at $25{ }^{\circ} \mathrm{C}$ should be $\leq 170 \mathrm{mS} / \mathrm{m}$, whereas the South African water guidelines limits for irrigation are 
0-40 $\mathrm{mS} / \mathrm{m}$ (equivalent to $0-400 \mu \mathrm{S} / \mathrm{cm}$ ). Both these limits were exceeded at all the points, especially MAL. Both MAL and ISD are upstream and close to each other and are located in a farming area. Since Dunoon is in a farming area, the high EC in MAL may be attributed to runoffs from the higher input of salts from agriculture, and in ISD may be due to domestic waste. This view is supported by Korkanç, who has indicated that an increase in conductivity can be attributed to anthropogenic discharges and runoff of wastewater into water bodies, thereby making the water unsuitable for domestic use and irrigation purposes (Islam and Islam 2020).

MGC downstream is far from agricultural activities and very close to Lagoon beach. The high EC at this point may be attributed to seawater intrusion, as Kumar and Libchaber (2013) have indicated that the intrusion of seawater into rivers in delta regions and coastal lines may also alter the EC, $\mathrm{pH}$, and TDS. In a study that was conducted in the Benue River in Nigeria, the results indicated lower conductivity during the dry season (Kumar and Libchaber 2013). This trend may be attributed to an increase in the concentration of organic and inorganic materials and salts because of runoff from domestic and other human activities into the river during the wet season, discharges by the feeder streams, and industrial effluents (Anhwange et al. 2012). A similar study by Awe showed that electrical conductivity values at the Milnerton Woodbridge (DC) site were higher than the acceptable range of $0-1500 \mu \mathrm{S} / \mathrm{cm}$ set by the Department of Water and Sanitation of South Africa, whereas the Table Bay Nature Reserve (DA) and Theo Marais (DB) sites were below $1500 \mu \mathrm{S} / \mathrm{cm}$ in all seasons except spring (Awe et al. 2020). The possible contributing factors to the high EC values were wastewater runoff into the rivers, river flows, and tidal waves.

\section{Salinity concentration on all four sampling sites}

Figure $2 \mathrm{~d}$ shows the analysis of salinity results for the four sites. MGC had the highest level of salinity with an average of 9.2 psu. PWP upstream had the lowest level at 1.3 psu. There was a huge difference between the highest and the lowest levels of salinity recorded. MGC was an outlier, and the other three sites were centered around the same mean. MGC in this analysis recorded the highest level of salinity on all the different days on which the measurements were taken. MGC is downstream and close to the sea and high salinity may be due to seawater intrusions. The level of salinity in the dry season was 4.1 times higher than that of the wet season because the river was not diluted $b$ rainwater.

Salinity is used to describe the total concentration of dissolved salts in water (Hussain et al. 2017). Naturally, the river or lake water with a salinity of about $70 \mathrm{mg} / \mathrm{L}$ will have a specific conductivity of between 80 and $13 \mu \mathrm{S} / \mathrm{cm}$ at $25^{\circ} \mathrm{C}$.
The real ratio depends on the existing ions (Van Niekerk et al. 2014). An increase in the volume or concentration of salinity in streams destroys town water supplies, affects agriculture and horticulture, and adversely impacts river ecosystems. Salinity can cause a decline in plant growth and water quality, resulting in lower crop yields and degradation of water supplies. Excessive salt has an impact on total soil health, decreasing productivity. It destroys plants, leaving bare soil that is susceptible to erosion (Minhas et al. 2020). MGC is close to the Lagoon beach and has more levels of salinity, and this may be because of seawater intrusion.

In a study conducted by Awe, the seasonal salinity values recorded at the different Diep River study sites ranged from 915 to $5231 \mathrm{mg} / \mathrm{L}$, while the seasonal range in this study was from 1.3 to 9.2 psu (equivalent to $1300-5300 \mathrm{mg} / \mathrm{L}$ ) (Awe et al. 2020). In Awe's study, most of the seasonal salinity values recorded at the studied Diep River sites were higher than the recommended acceptable value of less than $1000 \mathrm{mg} / \mathrm{L}$ for the protection of freshwater life. In this study, the Diep River exceeded the acceptable limit at all sites, with the dry season showing a higher average than the wet season. Awe's study recorded the highest salinity levels during spring (Awe et al. 2020).

Increased salinity in freshwater ecosystems can have an impact on community composition. The EC levels are affected by both geogenic and anthropogenic factors. The levels of salinity in water vary greatly and are related to natural processes such as rock weathering, rainfall, seawater intrusion, and aerosol deposits (Hien Le et al. 2021), as well as anthropogenic activities within the catchment including land development, solid waste, agricultural and industrial discharges, intensive fertilization and irrigation, and mining (Kaushal et al. 2018; Cañedo-Argüelles et al. 2013). In Germany, the potash industry is the primary anthropogenic source of salts in the river (Bäthe and Coring 2011; Schulz and Cañedo-Argüelles 2019). According to recent studies, geogenic and climatic factors are the primary natural drivers of ECs in surface water in Central Europe and Northern America (Olson and Hawkins 2012; Le et al. 2019). Increased salinity can have a variety of effects on aquatic organisms, including changes in chemical processes in the stream and direct harmful effects (Hien Le et al. 2021).

\section{Total suspended solids (TSS) concentration in all four sampling sites}

Figure $3 \mathrm{~b}$ shows the analysis of TSS results from the four collection points. The results show that PWP had the highest average with $148.3 \mathrm{mg} / \mathrm{L}$, while MGC had the lowest with $30.8 \mathrm{mg} / \mathrm{L}$. According to the South African water guidelines, the TSS levels for aquatic ecosystems should not exceed the limit of $100 \mathrm{mg} / \mathrm{L}$. The analysis shows that only PWP had an average that exceeded the limit. The other three sites 

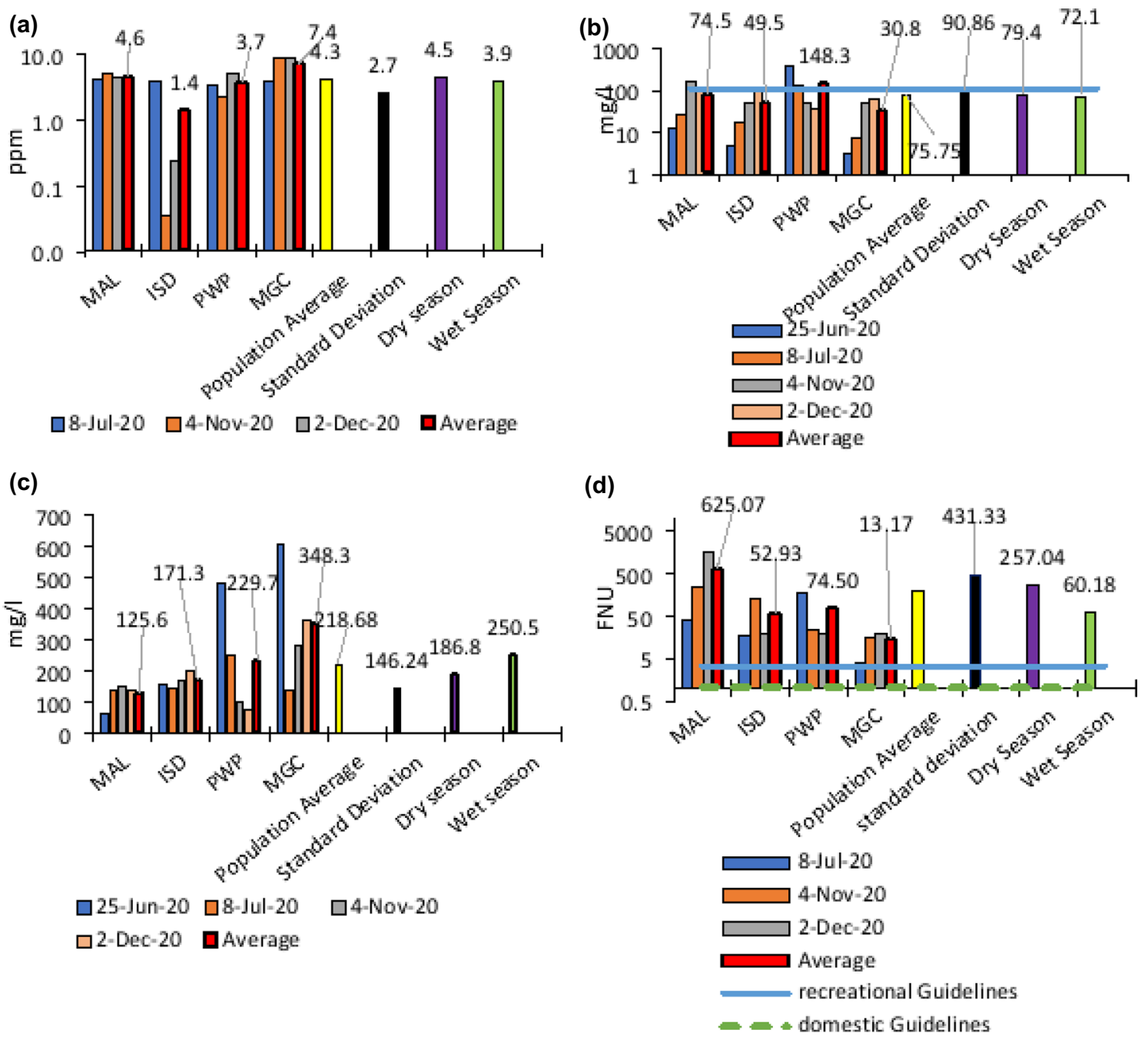

Fig. 3 Dissolved oxygen, total suspended solids, chemical oxygen demand, turbidity results

had TSS levels below the threshold but there was a major fluctuation in terms of the levels. This may be attributed to informal houses developed close to the river and runoffs that carry sediments from the development into the river.

The suspended material contains silt, clay, fine particles of organic and inorganic matter, soluble organic compounds, plankton, and other microscopic organisms. The existence of suspended solids is normally related to a reduction in the clarity of water; for example, light penetration or visibility (DEA 2018). Total suspended solids (TSS) carried by rain runoff water are recognized as one of the main sources of polluted sediments from urban settlements (Wakida et al. 2014). Torres and Bertrand-Krajewski (2008) also agree that several pollutants in urban rainy-weather discharges are connected to particles carried in suspension.

The seasonal averages in this study were below the $100 \mathrm{mg} / \mathrm{L}$ limits. TSS levels were high during the dry season, which had $79.4 \mathrm{mg} / \mathrm{L}$, compared to $72.1 \mathrm{mg} / \mathrm{L}$ in the wet season. These results contradicted those obtained in the study conducted in the Jukskei River, Alexandra by Matowanyika (2010), where the total suspended solids increased during the wet season and were low during the dry season. However, the results were similar to those obtained from the Chobe River in Botswana in a study by Fox and Alexander, which showed higher TSS levels during the dry season and lower TSS during the wet season (Torres and BertrandKrajewski 2008). This may be due to the different climatic regions, but it remains to be investigated by future studies.

\section{Chemical oxygen demand (COD) concentration in all four sampling sites}

Figure $3 \mathrm{c}$ shows the results of COD for samples that were collected in four different sites. MGC had the highest levels of COD with an average of $348.3 \mathrm{mg} / \mathrm{L}$. The lowest recorded levels were at MAL with an average of $125.6 \mathrm{mg} / \mathrm{L}$. This 
shows that the COD recorded at MGC was 2.5 times higher than that of MAL. The average level of COD recorded for the four locations over 4 months was $218.7 \mathrm{mg} / \mathrm{L}$. The results show that the levels of COD are not centered around the mean, indicating some fluctuations. The dry season had a lower average than the wet season.

High levels of COD indicate the existence of all kinds of biodegradable and nonbiodegradable organic matter, causing high levels of pollution (Islam et al. 2019). COD may also increase because of the death of bacteria cells. As the cells decompose, they release dissolved organic carbon, thus increasing COD. Low levels of COD in river systems indicate good water quality, while high levels indicate pollution and may cause harm to aquatic life, especially fish (Edokpayi et al. 2017). Surface water should have low COD to sustain human beings and fish. The South African water guidelines for wastewater recommend that COD levels should not exceed $75 \mathrm{mg} / \mathrm{L}$. The average COD results at all individual sites exceeded this limit, indicating that the river was highly polluted. The high concentration of COD in this study may be attributed to sewage and fertilizer that enters the river through runoffs, industrial effluents, and the Potsdam wastewater plant outfalls that are in proximity.

\section{Dissolved oxygen (DO) concentration in all four sampling sites}

Figure 3a shows the results of DO for the four collection points. MGC had the highest DO average at $7.4 \mathrm{ppm}$ while ISD had the lowest at $1.4 \mathrm{ppm}$. The difference between the MGC and ISD DO levels is very high, with the MGC average being five times higher than that at ISD. There is not much difference between the wet and dry season DO levels. The dry season average is slightly high with $4.5 \mathrm{ppm}$, compared to $3.9 \mathrm{ppm}$ during the wet season. Dissolved oxygen measures the amount of oxygen that is dissolved in water (USGS 2009). Some of the human issues that have an impact on dissolved oxygen in streams involve the addition of oxygen-consuming organic wastes; for example, sewage, changing the river flow, increasing the water temperature, and the adding of chemicals.

The low dissolved oxygen in ISD can be attributed to the slow-moving water at the point because of many reeds. Other contributing factors may be pollution through solid waste, sewage, and fertilizer that enter the river through runoffs. The PWP levels of dissolved oxygen may be attributed to the wastewater plant and other diffused sources. MAL is the closest point to ISD, but there is a huge variation in the levels of dissolved oxygen. The level of dissolved oxygen is mostly attributed to fertilizer, plastics, and solid waste entering the river. Of the four points, MGC downstream had the highest dissolved oxygen levels. This may be attributed to the rapid movement of water at that point.
Dissolved oxygen is one of the major elements that influence biochemical activities in water bodies. DO levels can be impacted by industrial, municipal, and agricultural waste discharges and sewer overflows into the river (Haider et al. 2013). The low amount of dissolved oxygen may threaten the ecosystem. Plastic and solid waste in the river may also affect the levels of dissolved oxygen, thereby affecting the ecosystem (Kulkarni 2016). Slow-moving water tends to have low dissolved oxygen than rapid-moving water. Bacteria from sewage and fertilizers can affect oxygen levels in rivers as the organic matter decomposes. According to another study, DO levels less than $5 \mathrm{mg} / \mathrm{L}$ could harm the aquatic ecosystem (Edokpayi et al. 2017). In all sites except MGC, the levels were less than $5 \mathrm{mg} / \mathrm{L}$, meaning that the aquatic life was compromised at the three sites. The average DO values during the wet and dry seasons were less than $5 \mathrm{mg} / \mathrm{L}$.

\section{Turbidity in all four sampling sites}

Figure $3 \mathrm{~d}$ shows the results of turbidity in the river for the four different sites. The MAL had the highest average levels of turbidity at $625.07 \mathrm{FNU}$, while the lowest was $13.17 \mathrm{FNU}$ at MGC. This means that the average turbidity level of MAL was 47 times higher than that of MGC. For recreational purposes, the turbidity levels should not exceed 3 NTU, whereas for domestic purposes the accepted range is $0-1$ NTU. (The NTU unit is equivalent to FNU). The turbidity levels at all four sampling sites exceeded this limit. The level of turbidity in the dry season was four times higher than that of the wet season. The average population for turbidity was 191.42 FNU.

Most studies show that during and after rainfalls, turbidity increases greatly because of sediments that are washed off into the stream. For example, in a study conducted by Eliku \& Leta in the Awash River in Ethiopia, the highest recorded mean turbidity value was 139.61 NTU during the wet season due to surface runoff from nearby agricultural land, while the lowest recorded average turbidity value was 36.4 NTU during the dry season (Eliku and Leta 2018). Similarly, in the Mvudi River in South Africa, the turbidity values recorded in winter during the dry season were 1.3-14.7 NTU, indicating a decrease as expected, while those recorded in the wet season were high, ranging between 13.3 and 473 NTU. The high values can be due to high frequencies of rainfall, leading to erosion and surface runoff transporting suspended materials into the water bodies (Edokpayi et al. 2015).

However, the study results showed higher turbidity in dry seasons, and this may be attributed to the disturbance of land activities in and around the Diep River, such as the expansion of the Dunoon informal settlement close to the river and the cleaning of the river (removing silt) during summer. 


\section{Ammonia concentration in all four sampling sites}

Table 1 shows the results for ammonia in all four sampled sites. The highest level of ammonia recorded in a single day was recorded at ISD, while the lowest was recorded at MAL. The highest average was recorded at PWP with $11.04 \mathrm{mg} / \mathrm{L}$ and the lowest was MAL which had $3.5 \mathrm{mg} / \mathrm{L}$. The average ammonia for PWP was three times higher than the lowest average recorded. The level of ammonia fluctuates greatly along the river. On average, the wet season had the highest levels of ammonia.

According to the South African National Standards for drinking water, the ammonia content should be $\leq 1.5 \mathrm{mg} / \mathrm{L}$ (SANS 2015). During both the dry and wet seasons, the average levels of ammonia exceeded the recommended limit. The increase during wet seasons may be attributed to waste from farming activities and sewage entering the river through runoffs in all sites. Looking at the results of OUTA's analysis of ammonia NH4 from the Diep River catchment, PDD recorded the highest levels of ammonia NH4 with an average of $25 \mathrm{mg} / \mathrm{L}$. Theo Marais Storm Water Drain recorded the lowest levels of ammonia with an average of $2.2 \mathrm{mg} / \mathrm{L}$, which is a huge difference from PDD (Greggorr 2020). There was a $22.8 \mathrm{mg} / \mathrm{L}$ difference between the highest average and the lowest average. There were major fluctuations between the results of all sites. Most of the sites in the graph have exceeded the South African National Standards limit of $\leq 1.5 \mathrm{mg} / \mathrm{L}$ (SANS 2015).

Extreme levels of ammonia can change the aquatic ecosystem, causing extensive eutrophication. This may trigger other environmental problems, such as nitrous oxide emission and depleted oxygen in the water bodies (Canfield et al. 2010). Literature has shown that excessive ammonia leads to eutrophication; for example, eutrophic conditions were observed in the Loloan River estuary in Bali, where high concentrations of ammonia were recorded (Suteja and Dirgayusa 2008).

\section{Phosphate concentration in all four sampling sites}

The results of phosphate are shown in Table 1. MAL had the lowest average phosphate level of $2.1 \mathrm{mg} / \mathrm{L}$, while ISD had the highest average $(3.8 \mathrm{mg} / \mathrm{L})$. The average level of phosphate recorded for the four locations over 4 months of recording was $2.75 \mathrm{mg} / \mathrm{L}$. This indicates that most of the results were centered around the mean. There was not much fluctuation of phosphate levels in the river. There were very few differences in the levels of phosphate recorded in all four locations. The dry season had a slightly higher average of $2.9 \mathrm{mg} / \mathrm{L}$ compared to $2.6 \mathrm{mg} / \mathrm{L}$ in the wet season.

Phosphate originates from animal wastes, sewage, detergents, fertilizers, disturbed land, and road salts used in the winter (Gautam et al. 2014). It is an essential nutrient for

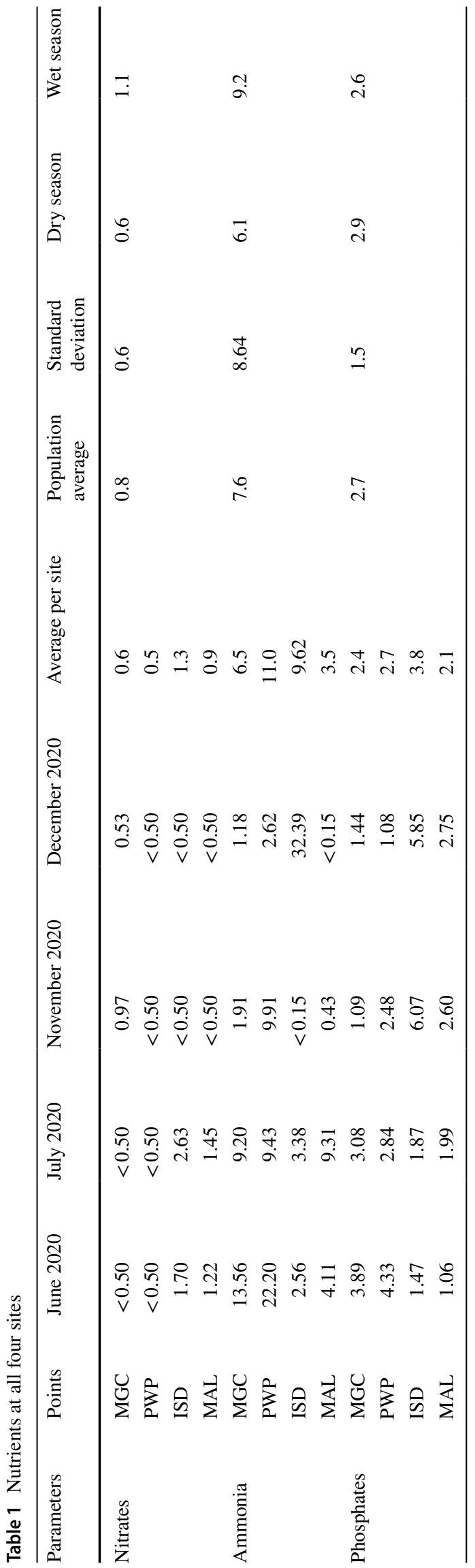


the development of organisms, and it is not categorized as a harmful or toxic element for mankind at low concentrations (Kumar and Puri 2012). The results obtained in this study were not in line with other similar studies which showed higher phosphate, especially during wet seasons. For example, the middle Umgeni River in KwaZulu-Natal experienced high levels of phosphate because of informal settlements lacking sanitation facilities, effluent from cattle feedlots, and poultry farms (DWAF 2011).

Despite all the activities in and around the Diep River, phosphate levels were within the limit of South African guidelines for aquatic ecosystems. This was in line with Griffin's results that indicated a steady rise in phosphate levels in South African freshwater over a while but have decreased sharply in recent times; a trend which cannot simply be ascribed to a single phosphate source (Griffin 2017). This trend is supported by the pairwise comparison which confirmed that the levels of phosphate increased from 1985 to $2008(p<0.001)$, then decreased until $2013(p<0.001)$ at sites across the country (Griffin 2017). Large amounts of phosphorus stimulate the growth of alga (eutrophication phenomenon), thereby limiting the penetration of sunlight and the circulation of carbon dioxide, leading to depleted dissolved oxygen levels in the aquatic ecosystem (Ngatia and Taylor 2018). As an example, the eutrophication phenomenon was also experienced in one of the sites by the Hartbeespoort Dam in South Africa where there were high levels of phosphates (Atta et al. 2020). A similar incident had occurred in the Diep River in 2006, which led to the death of tons of fish (Jackson et al. 2011).

\section{Nitrate concentration in all four sampling sites}

The analysis of nitrate results is shown in Table 1. ISD had the highest average nitrate levels of $1.3 \mathrm{mg} / \mathrm{L}$, while PWP had the lowest with $0.5 \mathrm{mg} / \mathrm{L}$. The South African water guidelines state that the amount of nitrate should be in the range of $0-100 \mathrm{mg} / \mathrm{L}$ for agricultural purposes (DWAF 1996). Extreme levels of nitrate are normally due to improper disposal of human and animal waste or the extensive use of chemical fertilizers (Garzon-Vidueira et al. 2020). The lack of sanitation facilities, effluent from cattle feedlots, and domestic waste may be the cause of high levels of nitrate in ISD. In the Dunoon informal settlement, there is also goat and pig farming, and animal waste may end up in the Diep River through runoffs. This is in line with the findings from a study conducted by Garzon-Vidueira et al. (2020).

Nitrates enter streams from natural sources such as decomposing plants, animal waste, and human causes like sewage or fertilizers. Concentrations of over $10 \mathrm{mg} / \mathrm{L}$ will affect the freshwater aquatic environment. The nitrate concentration in the river was within the South African water guidelines limit of $0-100 \mathrm{mg} / \mathrm{L}$ for agricultural use in both the dry and wet seasons and within the South African National Standards limit of $12 \mathrm{mg} / \mathrm{L}$. However, the wet season had higher concentrations than the dry season. The study results showed consistency with Nyamangara findings which indicated lower concentrations in the dry season and higher concentrations in the wet season (Nyamangara et al. 2013). The study was also in line with another study of the Jukskei River in Alexandra, which showed a rise in nitrate concentration in the rainy season (Matowanyika 2010).

Freshwater ecosystems are impacted by a variety of stressors, many of which are tied to land development. Elevated nutrient concentrations are common among these stressors. According to a German study, nutrients are present at levels over the risk limits for ecological damage at $85 \%$ of sites (Schäfer et al. 2016). Between 2005 and 2015, phosphate concentrations in Thuringian streams ranged from less than $(0.01-0.14 \mathrm{mg} / \mathrm{L})$, but nitrates were higher (3.4-50.8 mg/L). Phosphate concentrations in North Rhine-Westphalia streams ranged from below detection to $0.96 \mathrm{mg} / \mathrm{L}$, while nitrate values were $(2.3-60 \mathrm{mg} / \mathrm{L}$ ) (Schäfer et al. 2016). Increased nutrient levels may have contributed to the decline in invertebrate richness (Alexander et al. 2016). It was also noticed that a rise in nutrient concentration increased the abundance of the snail Physa acuta while having no effect on Viviparus georgianus (Lind et al. 2018).

\section{Comparison of water quality results from three Outa points}

Figure 4 shows a comparison between three Outa sites that had tests taken on most of the test days. Most of the OUTA points are in very close proximity. The reason for choosing the three points is that they are far apart and influenced by different land uses; for example, TMS, industries, and the waste treatment plant. M14 is mostly influenced by residential areas, both formal and informal, and MCC is a point close to the beach and downstream the waste treatment plant and Industries and informal residents and is used for recreational purposes. The quality of natural water differs from one place to another, subject to seasonal changes, soil and rock type, and the surface through which it flows. The quality of water is considerably changed by various human activities like mining and recreation, urban and industrial development, and agriculture (Kretzmann 2019).

The results show that there was no correlation between variables. A large value of a particular variable did not influence the value of other variables under test. The only variables that seemed to be correlated were $E$. coli and fecal coliforms, where each site that had the highest levels of $E$. coli also had the highest fecal coliform levels. 
Fig. 4 Comparison of M14, TMS, and MCC on all attributes
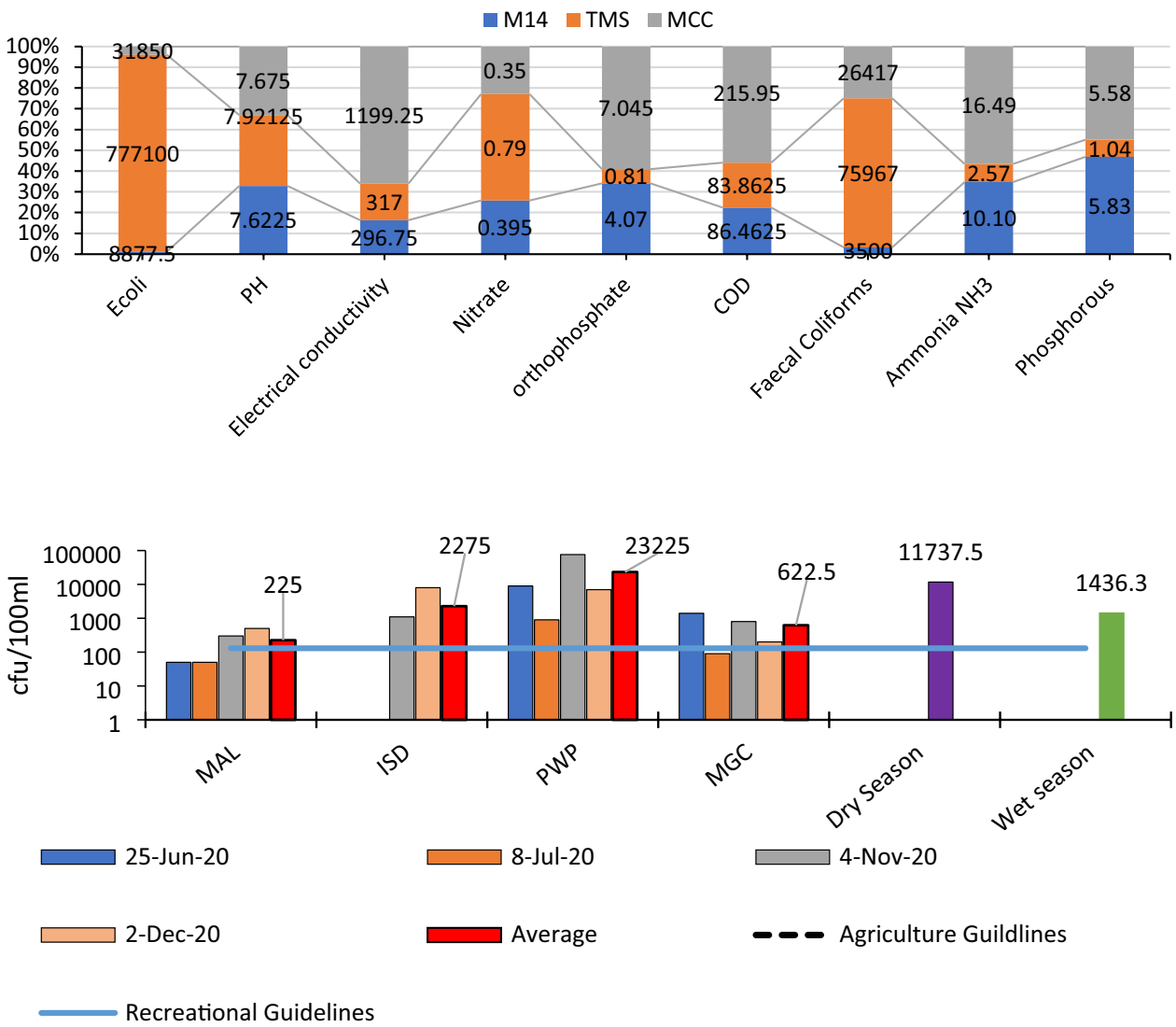

\section{E. coli concentration in all four sampling sites}

Figure 5 shows the $E$. coli results from four different points of the Diep River. The results show that PWP recorded the highest levels of E. coli. The water standard of South Africa states that the $E$. coli levels should not exceed $0 \mathrm{cfu} / 100 \mathrm{~mL}$ for irrigation and 0-130 cfu/100 mL for recreation purposes (DWAF 1996). All the average measurements exceeded these limits. MAL had the lowest average of $E$. coli with a value of $225 \mathrm{cfu} / 100 \mathrm{~mL}$. PWP had the highest average with $23,225 \mathrm{cfu} / 100 \mathrm{~mL}$, which is way above the prescribed limits. This high E. coli count could be attributed to the proximity of PWP to the Potsdam Wastewater Treatment Plant as the plant discharges its wastewater into the Diep River. The E. coli levels are higher during the dry season than the wet season.

All the points of the Diep River were contaminated by $E$. coli in summer, whereas the only ISD had $E$. coli levels undetected during the winter months. This could be because the $E$. coli levels were diluted by the rain and there were fewer shacks around the river. In most African countries, surface water is threatened by pollution caused by coliform bacteria and the situation poses risks to humans and the environment. Several cases of waterborne diseases have been attributed to $E$. coli as a contributing agent (Islam and Islam 2020).
Figure 5 shows that during both the wet and dry seasons, the average levels of E. coli exceeded the limits. This is in line with a study that was conducted in 2009 by Paulse et al. (2009), which also showed that the Diep River was highly contaminated with $E$. coli, exceeding the maximum limit for the river water throughout the study. The results in Paulse's study showed that the Theo Marais Sports Club site, which is surrounded by industrial, waste plant, and residential areas, was the most contaminated because of the waste effluent from these areas. The presence of $E$. coli in water used for recreational purposes, irrigation, or drinking purposes creates a possible risk for infections in animals and humans (Kümmerer 2009; Paulse et al. 2009).

\section{Fecal coliforms results}

Outa's fecal coliform results showed that M14 recorded the lowest levels of fecal coliform with an average of $3500 \mathrm{cfu} / 100 \mathrm{~mL}$. TMS had the highest level with $300,000 \mathrm{cfu} / 100 \mathrm{~mL}$, and the site had an average of $75,967 \mathrm{cfu} / 100 \mathrm{~mL}$. All the sites did not show any major fluctuations in terms of the test results, with most results being around the average of 75,967 cfu/100 mL (Greggorr 2020).

Both the lowest average fecal coliform count $(3500 \mathrm{cfu} / 100 \mathrm{~mL})$ recorded in $\mathrm{M} 14$, and the highest average $(75,967 \mathrm{cfu} / 100 \mathrm{~mL})$ recorded in Theo Marais exceeded 
the $0-150 \mathrm{cfu} / 100 \mathrm{~mL}$ range set for full contact recreation uses (DWAF 1996). The average level of fecal coliform recorded in all sites also exceeded the South African limit of $200 \mathrm{cfu} / 100 \mathrm{~mL}$ for water used for livestock watering. Therefore, the river water is not suitable for drinking and recreational purposes because it may cause disease and illness.

The results of research to examine faecal contamination in Gabon's coastal zone, focusing on the most heavily populated region of Libreville, were frightening, with rivers and beaches contaminated by sewage discharge exceeding recreational water safety requirements (WHO 2018; Leboulanger et al. 2021). According to Padovan et al. (2020), the report pattern recommended treatment to coastal marine water for the production of local fisheries via potentially harmful pathogens.

\section{Diep River water uses}

The majority of people indicated that they did not use the river water. Out of the 249 questionnaire responses, only 41 indicated that they used river water mostly for irrigation of gardens. Only five people indicated that they used the river water for cooking and drinking. A few questionnaires had contradictions as people said that the river water was not valuable for them, yet they also indicated that they used the river water. As per observations, the river was highly polluted and, according to the questionnaire responses, people who did not have tap water receive water from the municipality water truck. However, the respondents also indicated that the water received from the truck was not sufficient to meet their daily needs. It was also observed that the river was generally used for irrigation and for recreational purposes such as boating and fishing downstream Dunoon in Milnerton, even though signs were indicating that the river was polluted and should not be used for activities like boating, swimming, and so on.

\section{Disposal of solid waste in Dunoon}

Western Cape Government (2019) states that the waste produced should be stored correctly for easy collection and disposal by the relevant authority. On-site storage is of main importance due to public health concerns and aesthetic considerations. In the Dunoon informal settlement, the day-to-day waste generated through human activities is left to accumulate in dumpsites near the residential areas. The environment of Dunoon is highly polluted as the community lacks basic services and waste management services. Waste removal is a big problem in the Dunoon informal settlement and this, in turn, degrades the environment.

Most of the people dispose of waste (illegally) all around the place, in drains, wetlands, empty lands, Diep River, and around Diep River. A few of the people burn their waste in their yards. The burning of waste at dumpsites or individual dwellings causes air pollution. Various emissions from open burning are poisonous. Air pollutants can be a source of harmful health effects (Wiedinmyer et al. 2014). Burning trash can also result in particles finding their way into the river. Some of the problems in Dunoon informal settlement are sewage overspills and pollution due to solid waste that enters the stormwater drainage system (Fig. 6b, c). Several waste elements get carried away with the stormwater and gather into the Diep River. Though a portion of the waste is carried away with the stormwater, part of the waste blocks and clogs the stormwater drainage system. This can be dangerous because of the risk of flooding and destruction of housing structures and lives and may also pose health risks.

Littering and dumping into and around the Diep River is a common activity in the Dunoon informal settlement built at the edges of the river as shown in Fig. 6a. In the same way as Dunoon, the residents of Alexandra informal settlement litter and dump waste into the Jukskei River due to the lack of urban drainage infrastructure and inadequate waste removal. This has an impact on water quality and the environment. In wet seasons, contaminants are also regularly washed into the Jukskei River (Fitchett 2017).

\section{Disposal of greywater}

Greywater is defined as wastewater that is generated from household activities such as bathing and washing laundry and dishes (Sharaf and Liu 2021). The most common method to manage greywater in Dunoon informal settlement is to dispose of it onto the ground. A large amount of greywater is either discarded into the stormwater system, causing the pollution of downstream water bodies, or disposed of onto the ground in the settlement.

According to Carden et al. (2007a, b), the greywater produced in high-density informal mushrooming settlements across the major cities in South Africa is harmful from a pathogenic and salinity perspective and has to be handled as a sanitation problem and not as a drainage issue. An example of this is Langrug informal settlement in Franschhoek, where residents largely collect water from the toilet blocks using buckets. The water is generally used for bathing, laundry, and household cleaning and this results in the production of 'greywater', which is disposed of outside their residences. The greywater forms streams in drainage channels and flows into the Stiebeuels River, Franschhoek River, and ultimately the Berg River. Pollution levels in the Berg River have been rising every year, and this can substantially have an impact on the quality of fruit grown using the river water for irrigation (Roberts 2018). This is a similar case to the congested Dunoon informal settlement, where residents also dispose of greywater in open spaces close to the river. The disposed of greywater enters the river through runoffs, 

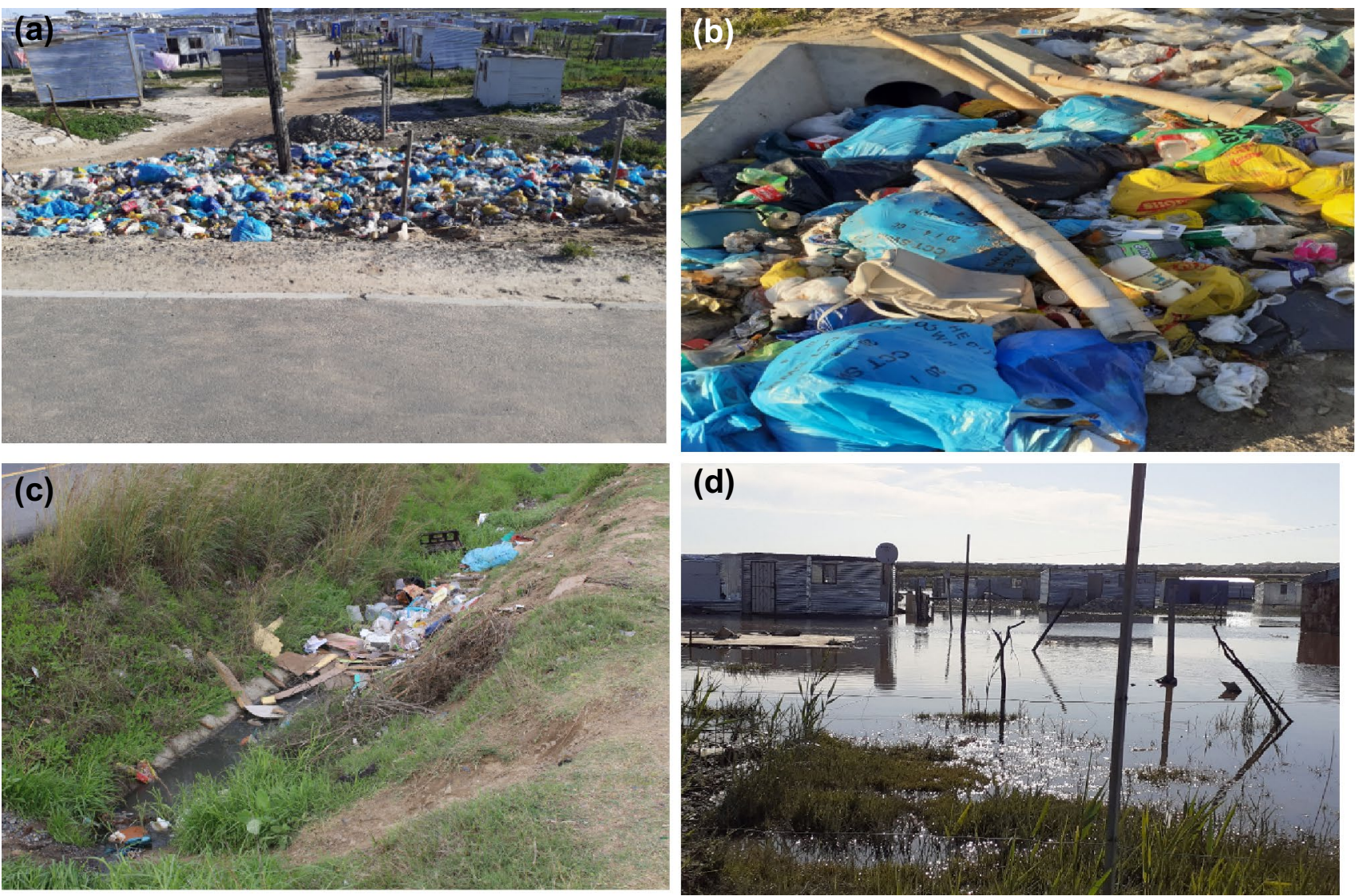

Fig. 6 Illegal disposal of waste and floods in Dunoon (Gqomfa 2020)

causing pollution. Carden et al. (2007a, b) state that it is important to ensure that residents in informal settlements are educated and empowered about managing greywater.

\section{Sanitation in Dunoon informal settlement}

Environmental hygiene plays an important part in preventing diseases. It also has a bearing on the natural environment and the protection of natural resources such as water. Adequate sanitation is essential for improving the environment (Hutton and Chase 2017). Dunoon informal settlement has a challenge of poor sanitation as the community uses shared communal toilets that are generally blocked and unhygienic. According to the questionnaire responses, about $84.74 \%$ of the respondents use shared exterior unflushed toilets (see Fig. 7). People prefer to help themselves in open land. This is evident in that one finds human waste in the paths of Dunoon informal settlement. Most of the shared toilets are unclean and full to the point that they leak to the outside and have no taps close by for people to wash their hands. Literature shows that this is common in most informal settlements within the African continent. Over $65 \%$ of the informal settlement residents lack access to adequate sanitation

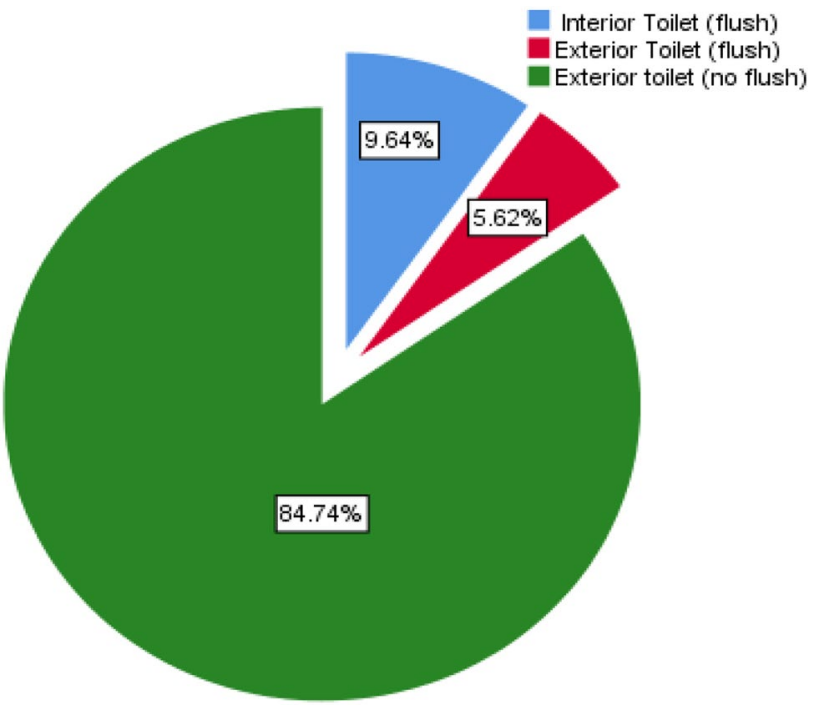

Fig. 7 Toilets used in Dunoon informal settlement

(UN-Habitat 2014), and this has been acknowledged as one of the major social issues of the post-apartheid period in South Africa (Masindi and Dunker 2016). 
McFarlane (2008) observed that in India, women chose to excrete human waste in open spaces rather than to use messy restrooms. Poor sanitation forces informal settlement dwellers to use nearby open spaces or unhygienic pit latrines (Buttenheim 2008). This was also observed in the Jarimeri informal settlement in Mumbai. The state of communal toilets in Jarimeri is bad, unclean, and lacks maintenance. Several individuals have made alternative in-house toilets. Those who cannot afford in-house toilets use public toilets or defecate in the banks of the Mithi River (Biswas et al. 2020). Similarly, some of the residents in the Dunoon informal settlement use open space and the riverbank as defecation zones due to dirty and blocked communal toilets. According to a Statistics SA (2016) media release, $45.6 \%$ of households in South Africa have no toilet inside their homes, and less than $50 \%$ of households have a toilet outside of their residence. Of the remaining $75.5 \%$ of people with access to sanitation, $12.2 \%$ have pit latrines, and $60.6 \%$ are connected to a sewerage system. In some informal settlements, toilets are shared; for example, in Ezindlovini in Khayelitsha, which is a settlement of more than 20,000 people sharing 380 communal toilets, some of the residents do not have toilet facilities at all. There have been protests and cries to the local government for help to address this problem (Anon 2016). Informal settlements lack centralized sewerage systems. According to WHO (2019), this lack of adequate sanitation in informal settlements is likely to cause diarrhoeal fatalities.

\section{Environmental impact and contamination}

The main causes of pollution in the Dunoon informal settlement were domestic sewage, agricultural waste, industrial waste, and solid waste. Based on the questionnaire responses, one of the major problems in Dunoon was solid waste management, although some sections of the informal settlement of Dunoon used bins to dispose of waste. Apart from the $57.9 \%$ who used bins, $52.5 \%$ used drains, $2.5 \%$ toilets, $49.6 \%$ open space, $32.2 \%$ burn waste, and $4.1 \%$ used other waste disposal methods. Some of the communities indicated that they burned their waste, causing air pollution. Many households admitted to disposing of human waste in harmful ways, which contributed to environmental degradation and contaminated river water. Most of the Dunoon informal settlement dwellers used an exterior non-flush toilet, a few used the exterior flush, and the backyard dwellers used interior flush toilets from the houses.

Literature shows that migrants in several targeted cities worldwide are compelled to cluster in areas characterized by unsafe tenure, inadequate access to basic services and labour markets, and exposure to environmental dangers such as flooding (Tacoli et al. 2015). Some studies have also indicated that there are vast environmental problems associated with informal settlements and low-income houses related to the location, drainage, and waste disposal. These studies argue that several low-income houses, including informal settlements, are located in unplanned land (French et al. 2021). For example, infrastructure such as water supply pipelines and electricity poles are not placed in a controlled way and hence they can trigger environmental problems. The people of Dunoon informal settlement live in unsafe residences with inadequate basic services. In the wet season, the houses are destroyed by floods as some parts of the settlement are located close to the river and other parts beneath the power lines (see Fig. 6d). This may result in fires and air pollution since the building material is highly flammable.

Environmental well-being could be adversely impacted by some contaminants. For instance, in some regions like Asia, the populations of vulture species have dropped significantly. This decline has been attributed to the veterinary use of diclofenac, which is a human pharmaceutical used to treat anti-inflammations (Petrik et al. 2017). It has also been associated with one of the active ingredients in the contraceptive pill associated with endocrine disruption and feminization in fish, called the ethynylestradiol (Petrik et al. 2017).

Vaal River supplies about $50 \%$ of Gauteng's water. Because of waste that gets dumped into the river stream, this river has been a target of water pollution. According to a News24 article written by Phakgadi (2019), vanadium and potassium carbonate were the chemicals found in the Vaal River (Phakgadi 2019). This affects the aquatic ecosystem and harms the environment.

\section{Health impact in Dunoon informal settlement}

In 2011, it was reported that diarrheal diseases accounted for deaths of more than 700,000 children below age 5 (Edokpayi et al. 2018). According to the World Health Organization (2017), water diseases are illnesses brought about by pathogenic micro-organisms that are transmitted in water bodies and that may spread while washing, drinking water, or by consumption of food exposed to polluted water.

In Dunoon, some of the respondents have suffered diseases like malaria, typhoid, cholera, asthma, diarrhoea, and skin disease due to the use or consumption of contaminated water. Skin diseases account for $57.3 \%$ of all the diseases suffered by the respondents as a result of using or consuming contaminated water, followed by diarrhoea with $33.6 \%$. Although some respondents indicated that they did not use river water, during flooding they are exposed to contaminated water. The contaminated water contains pathogens and chemicals that are a danger to human health and may result in skin diseases. Hence most respondents in the questionnaire indicated that they suffered from skin problems. Some of the problems related to diarrhoea may be due to poor water storage, poor sanitation, and poor waste disposal. 
Poor sanitation can result in exposure to faecal contamination through various environmental pathways, leading to undesirable health consequences. Exposure to faecalpolluted surface water has been confirmed to display an increased risk of helminth infections (Fuhrimann et al. 2017; Mather et al. 2020). The factors contributing to the urban sanitation crisis include insufficient water supply, poor drainage infrastructure, open defecation, poor faecal sludge management, and badly constructed or maintained sanitation facilities. They are worsened by inadequate solid waste management, high population density, and climate change, which consequently can raise the exposure to faecal pathogens (Hawkins et al. 2013). Similar to the above-mentioned studies, Dunoon is highly populated, lacks adequate sanitation, people defecate in open spaces, and dispose of waste on open land and drains. This poses high health risks amongst Dunoon informal settlement dwellers. See Table 2.

\section{Conclusion}

Rivers are sensitive and important ecosystems that have been extensively damaged globally. This study aimed to investigate the impact of informal settlement on the water quality of the Diep River in Dunoon. The literature revealed that there is a continual decline in the water quality in the Diep River. Human beings are often responsible for the main causes of water pollution in the Diep River. Results have also revealed that Diep River pollution is mostly due to noncompliance of the Wastewater treatment plant to legislation. Other factors contributing to the decline in the quality of water are the rise of urbanization, population growth, industrial production, and agricultural waste. The overcrowded informal settlements with inadequate sanitation are a major problem, coupled with the lack of other services such as waste collection. Due to a lack of such services, the health of

Table 2 Diseases because of water usage in Dunoon

\begin{tabular}{lccc}
\hline \multicolumn{3}{c}{ Diseases as a result of water usage in Dunoon } \\
\hline \multicolumn{2}{c}{ Responses } & \\
\cline { 2 - 3 } \multicolumn{4}{c}{ Percent of cases } \\
\hline Diseases resulting from use of water & \\
Malaria & 1 & 0.4 & 0.5 \\
Typhoid & 2 & 0.8 & 1.1 \\
Other diseases & 2 & 0.8 & 1.1 \\
Cholera & 8 & 3.2 & 4.4 \\
Asthma & 10 & 4.0 & 5.5 \\
Diarrhoea & 85 & 33.6 & 46.7 \\
Skin disease & 145 & 57.3 & 79.7 \\
Total & 253 & 100.0 & 139.0 \\
\hline
\end{tabular}

human beings is being negatively impacted by water-related diseases as the water bodies are extensively polluted.

The South African water quality guidelines for aquatic ecosystems, recreation, and agriculture were used for analysis. The average concentrations of E. coli, DO, electrical conductivity, salinity, turbidity, ammonia, and chemical oxygen demand exceeded the recommended limit in both the wet and dry seasons. The recommended limit for $E$. coli is $0 \mathrm{cfu} / 100 \mathrm{~mL}$ for irrigation and $0-130 \mathrm{cfu} / 100 \mathrm{~mL}$ for recreation purposes, but the average highest $E$. coli count was $1436.3 \mathrm{cfu} / 100 \mathrm{ml}$ in the wet season and $11,737.5 \mathrm{cfu} / 100 \mathrm{~mL}$ in the dry season. The average COD in the wet season was 250.5 and $186.8 \mathrm{mg} / \mathrm{L}$ in the dry season, higher than the recommended wastewater limit of $\leq 75 \mathrm{mg} / \mathrm{L}$. The EC averages in the wet season $(2453.3 \mu \mathrm{S} / \mathrm{cm})$ and the dry season $(32,208 \mu \mathrm{S} / \mathrm{cm})$ were both higher than the recommended limit of 0-40 $\mathrm{mS} / \mathrm{m}$ (equivalent to $0-400 \mu \mathrm{S} / \mathrm{cm}$ ), while the turbidity averages in the wet season (60.18 fnu) and the dry season (257.04 fnu) were also greater than the acceptable limit of 3 NTU for recreational purposes and 0-1 NTU for domestic use. The average ammonia in the wet season was 9.2 and $6.1 \mathrm{mg} / \mathrm{L}$ in the dry season. Both the wet and dry season averages exceeded the recommended limit of $\leq 1.5 \mathrm{mg} / \mathrm{L}$ for drinking water.

Based on the results of this study, the water quality of Diep River, particularly close to the Dunoon informal settlement (ISD) site, has declined. This was evidenced by the low average dissolved oxygen levels and the average $E$. coli levels that were higher than the acceptable limits. In a single day's recording in December, the ISD site had the highest ammonia levels. The average ammonia was also high. Even though the phosphate levels were within the acceptable limit, the ISD site recorded the highest average levels of phosphate. The highest average nitrate levels were recorded at the ISD site. This can be attributed to the overcrowded Dunoon informal settlement with inadequate sanitation and a lack of waste collection services. It is, therefore, necessary to improve the management of waste and sewage issues in the Dunoon informal settlement.

\section{Recommendations}

The degradation of urban rivers is a major problem in South Africa and, for this reason, the combination of water quality monitoring with water resource protection is crucial. The rapid growth in informal settlements is also a major concern in urban areas. Based on the findings of this research, the following measures and practices can be implemented to reduce and monitor the level of water pollution in the Diep River, associated with Dunoon informal settlement: 
- Basic services such as sanitation and waste collection need to be provided regularly in the Dunoon informal settlement to prevent river pollution.

- Constantly inspect and monitor water quality and runoff nearer to the cause of contamination within the Dunoon informal settlement

- The government should introduce programmes to educate the people in the informal settlements about river resources and about the importance of keeping the water clean.

- Apart from the different land use activities that degrade surface water, Dunoon informal settlements are located in a farming area with livestock and other animals, and there is a landfill just close these stressors, which may negatively impact the quality of groundwater in the long term. Currently, no studies have been conducted regarding the impact of pollution on ground water in the area. Further research on this is also required.

- The local, provincial, and national government and the different departments (such as the Departments of Human Settlement, Agriculture, Minerals, Water and Sanitation, and so on) need to work in harmony regarding water policies and governance as one activity in one department can affect the water resources.

- Continuously enforce and monitor legislation adherence by industries, water waste plants, farms, and all involved parties to prevent pollution.

- The growth of emerging river contaminants that are not commonly monitored requires proactive further research on the application of new techniques for better monitoring of water in water bodies.

- The Potsdam Wastewater Treatment Plant needs to improve its wastewater treatment techniques and methods to minimize the number of pollutants discharged into the Diep River. Potsdam treatment plant is currently undergoing modification. This may improve the operations and performance of the plant in the future. However, there is a need for alternative emergency measures to improve how the water plant operates.

Supplementary Information The online version contains supplementary material available at https://doi.org/10.1007/s40899-022-00629-w.

Acknowledgements The author wishes to acknowledge Vinlab for analyzing the water samples, and OUTA (Organization Undoing Tax Abuse) for granting permission to use some of their water sampling data in this paper.

Funding No funds, grants, or other support was received to conduct this study or to prepare this manuscript.

Availability of data and material Although the submitted work is original and has not been published elsewhere in any form or language, raw data from the Organisation Undoing Tax Abuse (OUTA) was used to compare the study findings against those of OUTA. The information can be requested from OUTA, whose details are available on their website https://www.outa.co.za/. Data and materials are available at the CPUT repository.

Code availability Not applicable.

\section{Declarations}

Conflict of interest The authors declare that there are no financial interests/personal relationships which may be considered as potential competing interests.

Ethics approval Ethical clearance to conduct the study was granted by the City of Cape Town and later approved by the Cape Peninsula University of Technology's Higher Degree Committee.

Consent to participate This paper does not include any human participants and/or animals.

Consent for publication The work described in this manuscript has not been published before and is not under consideration for publication anywhere else. It has been approved by all co-authors for publication.

Open Access This article is licensed under a Creative Commons Attribution 4.0 International License, which permits use, sharing, adaptation, distribution and reproduction in any medium or format, as long as you give appropriate credit to the original author(s) and the source, provide a link to the Creative Commons licence, and indicate if changes were made. The images or other third party material in this article are included in the article's Creative Commons licence, unless indicated otherwise in a credit line to the material. If material is not included in the article's Creative Commons licence and your intended use is not permitted by statutory regulation or exceeds the permitted use, you will need to obtain permission directly from the copyright holder. To view a copy of this licence, visit http://creativecommons.org/licenses/by/4.0/.

\section{References}

Alexander AC, Culp JM, Baird DJ, Cessna AJ (2016) Nutrient-insecticide interactions decouple density-dependent predation pressure in aquatic insects. Freshw Biol 61:2090-2101. https://doi.org/10. 1111/fwb.12711

Anhwange B, Agbaji E, Gimba EC (2012) Impact assessment of human activities and seasonal variation on River Benue, within Makurdi Metropolis. Int J Sci Technol 2(5):248-254

Anon (2016) Dying for a pee Khayelitsha residents battle for sanitation. Eyewitness News: 12, October 2016. https://ewn.co.za/2016/10/ 12/Dying-for-a-pee-Khayelitsha-residents-battle-for-sanitation. Accessed 21 June 2021.

Atta KPT, Maree JP Jr, Onyango MS, Mpenyana-Monyatsi L, Mujuru M (2020) Chemical phosphate removal from Hartbeespoort Dam water, South Africa. Water SA 46(4):610-614. https://doi.org/10. 17159/wsa/2020.v46.i4.9074

Awe AA, Opeolu BO, Olatunji OS, Fatoki OS, Jackson VA, Snyman R (2020) Occurrence and probabilistic risk assessment of PAHs in water and sediment samples of the Diep River, South Africa. Water SA 6(6):80-93. https://doi.org/10.1016/j.heliyon.2020. e04306

Bäthe J, Coring E (2011) Biological effects of anthropogenic salt-load on the aquatic Fauna: a synthesis of 17 years of biological survey 
on the rivers Werra and Weser. Limnologica 41(2):125-133. https://doi.org/10.1016/j.limno.2010.07.005

Biswas R, Arya K, Deshpande S (2020) More toilet infrastructures do not nullify open defecation: a perspective from squatter settlement in megacity Mumbai. Appl Water Sci 10(96):1-9. https://doi.org/ 10.1007/s13201-020-1169-4

Buttenheim AM (2008) The sanitation environment in urban slums: implications for child health. Popul Environ 30:26-47. https:// doi.org/10.1007/s11111-008-0074-9

Cañedo-Argüelles M, Kefford BJ, Piscart C, Prat N, Schäfer RB, Schulz C-J (2013) Salinisation of rivers: an urgent ecological issue. Environ Pollut 17:157-167. https://doi.org/10.1016/j.envpol.2012.10. 011

Canfield DE, Glazer AN, Falkowski PG (2010) The evolution and future of earth's nitrogen cycle. Science 330(6001):192-196. https://doi.org/10.1126/science. 1186120

Cao T, Wang S, Chen B (2019) Water shortage risk transferred through interprovincial trade in Northeast China. Energy Procedia 158:3865-3871. https://doi.org/10.1016/j.egypro.2019.01.859

Carden K, Armitage N, SichoneI O, Winter K (2007a) The use and disposal of greywater in the non-sewered areas of South Africa: part 2-greywater management options. Water SA 33(4):433-441. https://doi.org/10.4314/wsa.v33i4.52936

Carden K, Armitage N, Winter K, Sichone O, Rivett U, Kahonde J (2007b) The use and disposal of greywater in the non-sewered areas of South Africa: part 1-quantifying the greywater generated and assessing its quality. Water SA 33(4):425-432. https:// doi.org/10.4314/wsa.v33i4.52937

DEA (Department of Environmental Affairs) (2018) South African water quality guidelines for coastal marine waters-volume 1: natural environment and mariculture use. Department of Environmental Affairs, Cape Town

DWAF (Department of Water Affairs and Forestry) (1996) Water quality guidelines, vol 8. Field guide, 1 st edn. Department of Water Affairs and Forestry, South Africa, pp 2-68

DWAF (Department of Water Affairs and Forestry) (2011) Health of rivers: Department of Water Affairs briefing. https://pmg.org.za/ committee-meeting/13243/. Accessed 06 Mar 2020

DWS (Department of Water and Sanitation) (2020). South Africa: Part 1 of 3. Government Gazette, p 1-292

Edokpayi JN, Odiyo JO, Msagati TAM, Potgieter N (2015) Temporal variations in physico-chemical and microbiological characteristics of Mvudi river, South Africa. Int J Environ Res Public Health 12(4):4128-4140. https://doi.org/10.3390/ijerph120404128

Edokpayi JN, Odiyo JO, Durowoju OS (2017) Impact of wastewater on surface water quality in developing countries: a case study of South Africa, Water Quality, Hlanganani Tutu, IntechOpen. https://doi.org/10.5772/66561, https://www.intechopen.com/chapt ers/53194. Accessed 15 Jan 2021

Edokpayi JN, Rogawski ET, Kahler DM, Hill CL, Reynolds C, Nyathi E, Smith JA, Odiyo JO, Samie A, Bessong P, Dillingham R (2018) Challenges to sustainable safe drinking water: a case study of water quality and use across seasons in rural communities in Limpopo province, South Africa. Water 10(2):159. https://doi.org/10. 3390/w10020159

Eliku T, Leta S (2018) Spatial and seasonal variation in physicochemical parameters and heavy metals in Awash River, Ethiopia. Appl Water Sci 8(6):1-13. https://doi.org/10.1007/s13201-018-0803-x

Fitchett A (2017) SuDS for managing surface water in Diepsloot informal settlement, Johannesburg, South Africa. Water SA 43(2):113. https://doi.org/10.4314/wsa.v43i2.14

French M, Trundle A, Korte I, Koto C (2021) Climate resilience in urban informal settlements: towards a transformative upgrading agenda. In: de Graaf-van Dinther R (ed) Climate resilient urban areas. Palgrave studies in climate resilient societies. Palgrave Macmillan, Cham
Fuhrimann S, Nauta M, Pham-Duc P, Tram NT, Nguyen-Viet H, Utzinger J, Cissé G, Winkler MS (2017) Disease burden due to gastrointestinal infections among people living along the major wastewater system in Hanoi, Vietnam. Adv Water Resour 108:439-449. https://doi.org/10.1016/j.advwatres.2016.12.010

Garzon-Vidueira R, Rial-Otero R, Garcia-Nocelo ML, Rivas-Gonzalez E, Moure-Gonzalez D, Fompedriña-Roca D, Vadillo-Santos I, Simal-Gandara J (2020) Identification of nitrates origin in Limia river basin and pollution-determinant factors. Agr Ecosyst Environ 290:106775. https://doi.org/10.1016/j.agee.2019.106775

Gautam RK, Banerjee S, Gautam PK, Chattopadhyaya M (2014) Remediation technologies for phosphate removal from wastewater: an overview. In: Daniels J (ed) Advances in environmental research, vol 36. Nova Science Publishers Inc, New York

Gqomfa B (2020) The impact of informal settlement on water quality of Diep River in Dunoon. Masters dissertation, Cape Peninsula University of Technology, Cape Town

Greggorr CA (2020) Diep River sampling report—06 May sample. Cape Town

Griffin NJ (2017) The rise and fall of dissolved phosphate in South African rivers. S Afr J Sci 113(11-12):1-7

Haider H, Ali W, Haydar SA (2013) Review of dissolved oxygen and biochemical oxygen demand models for large rivers. Pak J Eng Appl Sci 12:127-142

Hawkins P, Blackett I, Heymans C (2013) Poor-inclusive urban sanitation: an overview targeting the urban poor and improving services in small towns. Water and Sanitation program: study. https://www. wsp.org/sites/wsp.org/files/publications/WSP-Poor-InclusiveUrban-Sanitation-Overview.pdf. Accessed 23 Oct 2020

Hussain I, Das M, Ahamad KU, Nath P (2017) Water salinity detection using a smartphone. Sens Actuators B Chem 239:1042-1050. https://doi.org/10.1016/j.snb.2016.08.102

Hutton G, Chase C (2017) Water supply, sanitation, and hygiene. In: Mock CN, Nugent R, Kobusingye O et al (eds) Injury prevention and environmental health, 3rd ed. The International Bank for Reconstruction and Development/The World Bank, Washington. 2017 Oct 27. Chapter 9. https://www.ncbi.nlm.nih.gov/books/ NBK525207/. https://doi.org/10.1596/978-1-4648-0522-6_ch9. Accessed 01 Aug 2021

Islam MMM, Islam MA (2020) Quantifying public health risks from exposure to waterborne pathogens during river bathing as a basis for reduction of disease burden. J Water Health 18(3):292-305. https://doi.org/10.2166/wh.2020.045

Islam MMM, Shafi S, Bandh SA, Shameem N (eds) (2019) Impact of environmental changes and human activities on bacterial diversity of lakes. In: Freshwater microbiology: perspectives of bacterial dynamics in lake ecosystems. Academic Press, Cambridge, p 105-136

Jackson L, Conrad J, Carstens M (2011) Estuary management plan for the Diep estuary. CAPE estuaries programme: coastal \& environmental consulting. http://friendsofrietvlei.co.za/documents/ Diep-River-Estuary-Management-Plan.pdf. Accessed 06 Feb 2020

Kaushal SS, Likens GE, Pace ML, Utz RM, Haq S, Gorman J, Grese M (2018) Freshwater salinization syndrome on a continental scale. Proc Natl Acad Sci 115(4):E574-E583. https://doi.org/10.1073/ pnas. 1711234115

Kretzmann S (2019) Cape Town fails to publish water quality tests for two years. GroundUp. https://www.groundup.org.za/article/ city-fails-publish-water-quality-tests-two-years/. Accessed 27 Mar 2020

Kulkarni SJ (2016) A review on research and studies on dissolved oxygen and its affecting parameters. Int J Res Rev 3(8):18

Kumar P, Libchaber A (2013) Pressure and temperature dependence of growth and morphology of Escherichia coli: experiments and stochastic model. Biophys J 105(3):783-793. https://doi.org/10. 1016/j.bpj.2013.06.029 
Kumar M, Puri A (2012) A review of permissible limits of drinking water. Indian J Occup Environ Med 16(1):40-44. https://doi.org/ 10.4103/0019-5278.99696

Kümmerer K (2009) Antibiotics in the aquatic environment-a review-part I. Chemosphere 75(4):417-434. https://doi.org/10. 1016/j.chemosphere.2008.11.086

Le TDH, Kattwinkel M, Schützenmeister K, Olson JR, Hawkins CP, Schäfer RB (2019) Predicting current and future background ion concentrations in German surface water under climate change. Philos Trans R Soc B Biol Sci B. https://doi.org/10.1098/rstb. 2018.0004

Hien Le TD, Schreiner VC, Kattwinkel M, Schäfer RB (2021) Invertebrate turnover along gradients of anthropogenic salinisation in rivers of two German regions. Sci Total Environ 753:1-10. https:// doi.org/10.1016/j.scitotenv.2020.141986

Leboulanger C, Biluka KL, Nzigou A-R, Kenmogne VD, Happi JLM, Ngohang FE, Eleng AS, Abaga NOZ, Bouvy M (2021) Urban inputs of fecal bacteria to the coastal zone of Libreville, Gabon, Central Western Africa. Mar Pollut Bull 168:1-7. https://doi.org/ 10.1016/j.marpolbul.2021.112478

Lind L, Schuler MS, Hintz WD, Stoler AB, Jones DK, Mattes BM, Relyea RA (2018) Salty fertile lakes: how salinization and eutrophication alter the structure of freshwater communities. Ecosphere 9(9):e02383. https://doi.org/10.1002/ecs2.2383

Masindi V, Dunker LC (2016) State of water and sanitation in South Africa. CSIR Built Environment. https://www.researchgate.net/ publication/311451788_State_of_Water_and_Sanitation_in_ South_Africa. Accessed 27 July 2021

Mather W, Hutchings P, Budge S, Jeffrey P (2020) Association between water and sanitation service levels and soil-transmitted helminth infection risk factors: a cross-sectional study in rural Rwanda. Trans R Soc Trop Med Hyg 114(5):332-338. https://doi.org/10. 1093/trstmh/trz119

Mathur A (2015) Conductivity: water quality assessment. Int J Eng Res Technol 3(3):1-3

Matowanyika W (2010) Impact of Alexandra Township on the water quality of the Jukskei River. Dissertation, University of the Witwatersrand, Johannesburg

Mawela AS (2008) the level of environmental education awareness regarding water pollution-related diseases by learners who live in the Stjwetla informal settlement adjacent to the Jukskei River in Alexandra. University of South Africa, Pretoria

Mbui D (2019) I looked at how polluted Nairobi River is. The Conversation, Nairobi

McFarlane C (2008) Sanitation in Mumbai's informal settlement: state, 'slum' and infrastructure. J Environ Plan A Econ Space 40(1):88107. https://doi.org/10.1068/a39221

Minhas PS, Ramos TB, Ben-Gal A, Pereira LS (2020) Coping with salinity in irrigated agriculture: crop evapotranspiration and water management issues. Agric Water Manag 227:105832. https://doi. org/10.1016/j.agwat.2019.105832

Ngatia L, Taylor R (2018) Phosphorus eutrophication and mitigation. Strategies. https://doi.org/10.5772/intechopen.79173

Nyamangara J, Jeke N, Rurinda J (2013) Long-term nitrate and phosphate loading of river water in the Upper Manyame Catchment, Zimbabwe. Water SA 39(5):637-642. https://doi.org/10.4314/ wsa.v39i5.7

Olson JR, Hawkins CP (2012) Predicting natural base-flow stream water chemistry in the western United States. Water Resour Res. https://doi.org/10.1029/2011WR011088

Padovan A, Kennedy K, Rose D, Gibb K (2020) Microbial quality of wild shellfish in a tropical estuary subject to treated effluent discharge. Environ Res 181:108921. https://doi.org/10.1016/j. envres.2019.108921

Paulse AN, Jackson VA, Khan W (2009) Comparison of microbial contamination at various sites along the Plankenburg and Diep
Rivers, Western Cape, South Africa. Water SA 35(4):469-478. https://doi.org/10.4314/wsa.v35i4.76808

Petrik L, Green L, Abegunde AP, Zackon M, Sanusi CY, Barnes J (2017) Desalination and seawater quality at Green Point, Cape Town: a study on the effects of marine sewage outfalls. S Afr J Sci 113(11-12):1-10. https://doi.org/10.17159/sajs.2017/a0244

Phakgadi P (2019) Sasol denies claims it intentionally polluted Vaal River. News24: 22, February 2019. https://www.news24.com/ news24/southafrica/news/sasol-denies-claims-it-intentionallypolluted-vaal-river-20190222. Accessed 13 Mar 2020

Roberts R (2018) Innovating sanitation provision to informal settlement. https://www.isidima.net/single-post/2018/03/26/Innov ating-sanitation-provision-to-informal-settlement. Accessed 19 Nov 2020

SANS (South African National Standard) (2015) South African National Standard: drinking water (241:2015). https://www.mwa. co.th/download/prd01/iDW_standard/South_African_Water_ Standard_SANS_241-2015.pdf. Accessed 27 Feb 2021

Schäfer RB, Kühn B, Malaj E, König A, Gergs R (2016) Contribution of organic toxicants to multiple stress in river ecosystems. Freshw Biol 61:2116-2128. https://doi.org/10.1111/fwb.12811

Schulz C-J, Cañedo-Argüelles M (2019) Lost in translation: the German literature on freshwater salinization. Philos Trans R Soc B Biol Sci. https://doi.org/10.1098/rstb.2018.0007

SDWF (Safe Drinking Water Foundation) (2018) Water temperature fact sheet: why water temperature is important. https://www.safew ater.org/fact-sheets-1/2018/8/15/water-temperature-fact-sheet. Accessed 18 July 2021

Sharaf A, Liu Y (2021) Mechanisms and kinetics of greywater treatment using biologically active granular activated carbon. Chemosphere 263:128113. https://doi.org/10.1016/j.chemosphere. 2020.128113

Statistics SA (2016) Media release: community survey 2016 results. http://www.statssa.gov.za/?p=8150 Accessed 03 Feb 2020.

Suteja Y, Dirgayusa GP (2008) Detection of eutrophication in Benoa Bay-Bali. Omni-Akuatika 14(3):18-25. https://doi.org/10. 20884/1.oa.2018.14.3.490

Tacoli C, McGranahan G, Satterthwaite D (2015) Urbanisation, ruralurban migration and urban poverty. Working paper, Human Settlements Group, International Institute for Environment and Development

Torres A, Bertrand-Krajewski JL (2008) Evaluation of uncertainties in settling velocities of particles in urban stormwater runoff. Water Sci Technol 57(9):1389-1396. https://doi.org/10.2166/wst.2008. 307

Tsenkova S (2010) Informal settlements in post-communist cities: diversity factors and patterns. Urbani Izziv 21(2):73-84. https:// doi.org/10.5379/urbani-izziv-en-2010-21-02-001

Uddin MN, Alam MS, Mobin MN, Miah MA (2014) An Assessment of the river water quality parameters: a case of Jamuna River. J Environ Sci Nat Resour 7(1):249-256. https://doi.org/10.3329/ jesnr.v7i1.22179

UN-Habitat (2014) The State of African cities 2014: re-imagining sustainable urban transitions. Nairobi: UN-Habitat. https://unhabitat. $\mathrm{org} / \mathrm{state}$-of-african-cities-2014-re-imagining-sustainable-urbantransitions. Accessed 19 Nov 2020

USGS (2009) Dissolved oxygen and water. https://www.usgs.gov/speci al-topic/water-science-school/science/dissolved-oxygen-andwater?qt-science_center_objects=0\#qt-science_center_objects. Accessed 17 Nov 2019

Van Niekerk H, Silberbauer MJ, Maluleke M (2014) Geographical differences in the relationship between total dissolved solids and electrical conductivity in South African rivers. Water SA 40(1):133-138. https://doi.org/10.4314/wsa.v40i1.16

Wakida FT, Martinez-Huato S, Garcia-Flores E, Piñon-Colin TDJ, Espinoza-Gomez H, Ames-López A (2014) Pollutant 
association with suspended solids in stormwater in Tijuana, Mexico. Int J Environ Sci Technol 11:319-326. https://doi.org/ 10.1007/s13762-013-0214-3

Western Cape Government (2019) A guide to separation of waste at source. https://www.westerncape.gov.za/eadp/files/atoms/files/ WCape \%20Govt\%20Municipal\%20S\%40S\%20E-Guide_\%2010\% 20-9\%20-19Final.pdf. Accessed 18 July 2021

Western Cape Government (2020) Statement: actions taken on Diep River pollution concerns. https://www.westerncape.gov.za/news/ statement-actions-taken-diep-river-pollution-concerns. Accessed 18 July 2021

WHO (World Health Organization) (2018) WHO recommendations on scientific, analytical and epidemiological developments relevant to the parameters for bathing water quality in the Bathing Water Directive (2006/7/EC. WHO, Geneva, p 96

WHO (World Health Organization) (2019) Sanitation. https://www. who.int/news-room/fact-sheets/detail/sanitation. Accessed 21 Nov 2019

World Health Organization (2017) Guidelines for drinking-water quality: fourth edition incorporating the first addendum. Geneva:
World Health Organization. https://www.ncbi.nlm.nih.gov/books/ NBK442376/. Accessed 17 Jan 2021

Wiedinmyer C, Yokelson RJ, Gullett BK (2014) Global emissions of trace gases, particulate matter, and hazardous air pollutants from open burning of domestic waste. Environ Sci Technol 48(16):9523-9530. https://doi.org/10.1021/es502250z

Wolf MA, Sfriso A, Moro I (2014) Thermal pollution and settlement of new tropical alien species: the case of Grateloupia yinggehaiensis (Rhodophyta) in the Venice Lagoon. Estuar Coast Shelf Sci 147:11-16. https://doi.org/10.1016/j.ecss.2014.05.020

Xue CH, Yin HL, Xie M (2015) Development of integrated catchment and water quality model for urban rivers. J Hydrodyn 27(4):593603. https://doi.org/10.1016/S1001-6058(15)60521-2

Publisher's Note Springer Nature remains neutral with regard to jurisdictional claims in published maps and institutional affiliations. 